\begin{tabular}{|c|c|c|}
\hline Teologia & Pótroczznilk Wydziału Teologicznego UMK \\
\hline Cztowiek & $10(2007)$ & ISSN 1731-5638
\end{tabular}

KS. KRZYSZTOF LEWANDOWSKI*

TORUŃ

\title{
OPINIE PRASOWE O JANIE PAWLE II NA ŁAMACH „RZECZPOSPOLITEJ” W 2005 ROKU
}

\section{WSTĘP}

Prasa współczesna stanowi istotny środek społecznego przekazu. Nazywana bywa "lustrem społeczeństwa"1. Filozof niemiecki G. W. F. Hegel twierdził, iż czytanie prasy to „modlitwa poranna współczesnego człowieka"'2. W związku z rolą, jaką prasa odgrywa, stała się ona przedmiotem badań prasoznawczych. Na gruncie polskim mówi się o dwóch podstawowych gatunkach dziennikarskich. Pierwszą grupę stanowią gatunki informacyjne, które mają za zadanie powiadomienie o faktach. Są to: wzmianki, wiadomości, sprawozdania. Do drugiej grupy zalicza się gatunki o funkcjach opiniotwórczych, takie jak: artykuły, komentarze, recenzje ${ }^{3}$.

$\mathrm{W}$ prasie codziennej najważniejszym gatunkiem informacyjnym jest wiadomość, która obecnie zastępowana i wręcz wypierana jest angielskim słowem news, które oznacza „nowość”, „świeżą wiadomość”. W komuni-

* Ks. Krzysztof Lewandowski - doktor teologii pastoralnej, adiunkt na WT UMK w Toruniu, rektor WSD w Toruniu.

${ }^{1}$ S. Pamuła, III Rzeczpospolita w prasie, Częstochowa 2002, s. 8.

${ }^{2}$ Cyt. za: P. Murialdi, Come si legge un giornale, Roma-Bari 1982, s. VII.

${ }^{3}$ Zob. S. Pamuła, dz. cyt., s. 33-34. 
kacji społecznej jest to słowo używane coraz częściej, bez tłumaczenia go na język ojczysty. News dzieli się na hard news (twarda wiadomość) i na soft news (miękka wiadomość). Termin pierwszy odnosi się do informacji dramatycznej z zakresu życia społeczno-politycznego i gospodarczego oraz z zakresu kroniki, drugi natomiast dotyczy życia codziennego, nie obejmuje zaś spraw dramatycznych i nie domaga się natychmiastowego przekazania. Wiadomość winna odpowiedzieć na pytania: kto? gdzie? kiedy? co? dlaczego? Wyróżnia się także informację czystą, która odnosi się do faktu, oraz informację skomentowaną (zbeletryzowaną), która posiada akcent edukacyjny ${ }^{4}$.

Głównym gatunkiem opiniotwórczym jest artykuł. Jest to wypowiedź prasowa na aktualne tematy społeczne, polityczne, kulturalne, ekonomiczne, religijne i inne. Prezentuje stanowisko autora bądź redakcji i ma oddziaływać na opinię publiczną. Wyróżnić można artykuł wstępny, umieszczany na stronie tytułowej w eksponowanym miejscu, artykuł redakcyjny, dyskusyjny, polemiczny, okolicznościowy, popularnonaukowy, religijny ${ }^{5}$.

Jednym z najbardziej opiniotwórczych dzienników ogólnopolskich jest „Rzeczpospolita” („,Rz") ${ }^{6}$. Na jej łamach dość często gości problematyka religijno-kościelna $\mathrm{i}$ to zarówno $\mathrm{w}$ wymiarze informacyjnym, jak i publicystycznym. Przedstawiane i komentowane są wydarzenia z życia Kościoła Powszechnego oraz Kościoła w Polsce, a także innych wyznań i religii. Poruszana jest również szeroko pojęta problematyka religijna i moralna. Jest to pismo o charakterze laickim. Sprawy religijne, moralne i kościelne przedstawiane są w sposób zróżnicowany światopoglądowo. Na wspomniane wyżej tematy wypowiadają się dziennikarze, publicyści, duchowni, filozofowie, teolodzy, socjologowie i politycy różnych opcji politycznych, światopoglądowych oraz różnych wyznan. Wśród dziennikarzy i publicystów „Rzeczpospolitej”, którzy poruszają problematykę kościelno-religijną należy wymienić przede wszystkim: E. Czaczkowską, J. Sadeckiego i J. Moskwę. Ten ostatni jest korespondentem gazety $\mathrm{w}$ Rzymie.

Tematem niniejszego opracowania będzie analiza tekstów poświęconych problematyce związanej z osobą i działalnością Jana Pawła II w 2005,

${ }^{4}$ Zob. tenże, Stownik komunikacji społecznej Kościoła, Częstochowa 1997, s. 259-260.

${ }^{5}$ Zob. tamże, s. 20.

${ }^{6}$ Udziałowcami „Rz" są norweska spółka „Orkla” (51\% akcji) oraz Państwowe Wydawnictwo Rzeczpospolita S.A. (49\% akcji), zaś wydawcą „Presspublica”. Funkcję redaktora pełnił Grzegorz Gauden, obecnie jest nim Paweł Lisiecki. 
a więc w roku Jego śmierci, które ukazały się na łamach dziennika „Rzeczpospolita" w wydaniu ogólnopolskim na tzw. stronach białych ${ }^{7}$. Był to rok z kilku powodów szczególny. Dla Kościoła najistotniejszymi wydarzeniami była śmierć Jana Pawła II, która zakończyła blisko 27-letni pontyfikat, który znacznie wpłynął na życie i działalność Kościoła, historię Polski i Europy. Drugim ważnym wydarzeniem był wybór dotychczasowego Prefekta Kongregacji Nauki Wiary, niemieckiego kardynała Józefa Ratzingera na następcę św. Piotra. Przyjął On imię Benedykta XVI. Z dużym zaciekawieniem obserwowano pierwsze miesiące nowego pontyfikatu.

Jan Paweł II przypisał mediom ważną rolę w działalności ewangelizacyjnej. Zdając sobie sprawę z siły ich oddziaływania na ludzi, rozumiejąc mechanizmy tego oddziaływania, od początku pontyfikatu włączył je w szeroko pojętą działalność pastoralną Kościoła. Ta działalność związana z Jego osobą stała się przedmiotem zainteresowania dziennikarzy i mediów. Swoistym apogeum były ostatnie miesiące Jego pontyfikatu.

\section{CHOROBA JANA PAWŁA ll}

O samej postaci Jana Pawła II i jego działalności na łamach „Rzeczpospolitej” w roku 2005 ukazało się bardzo dużo publikacji zarówno informacyjnych, jak i opiniotwórczych. Już w pierwszym numerze zamieszczono informację o papieskiej modlitwie za ofiary Tsunami w Azji Południowo-Wschodniej ${ }^{8}$. Znakomita większość doniesień wiązała się przede wszystkim z Jego chorobą, jak się okazało śmiertelną. Obok samych informacji o stanie zdrowia i o pobytach $\mathrm{w}$ szpitalu, spekulowano także na temat możliwości ustąpienia $\mathrm{z}$ urzędu oraz o kandydatach na następcę Jana Pawła II. Jeszcze na początku stycznia spodziewano się dużej aktywności Papieża. Podano do wiadomości, iż planuje On pielgrzymkę do Serbii ${ }^{9}$, a w kilka dni później w dzienniku znalazła się informacja o tym, iż Ojciec św. nie wybiera się do Polski. Powodem miały być wybory parlamentarne i prezydenckie oraz niestabilny stan zdrowia Papieża. Planował jednak wyjazd do Kolonii na spotkanie z młodzieżą. Poinformowano także, iż Jan Paweł II po raz pierwszy nie udzielił sakramentu chrztu św.,

\footnotetext{
${ }^{7} \mathrm{~W}$ odróżnieniu od stron zielonych poświęconych problematyce gospodarczej i ekonomicznej oraz stron żółtych poświęconych problematyce prawnej.

${ }^{8}$ Zob. J. Moskwa, Modlitwa za ofiary, „Rz” 2005, nr 1, s. 7.

${ }^{9}$ Zob. Beta, Jan Pawet II wybiera się do Serbii, „Rz” 2005, nr 2, s. 6.
} 
jak to miał w zwyczaju czynić we wszystkie Niedziele Chrztu Pańskiego podczas całego swego pontyfikatu ${ }^{10}$.

W styczniowych wydaniach „Rzeczpospolitej” znaleźć można także informacje o opublikowanych przez Stolicę Apostolską istotnych dokumentach papieskich. Chodzi mianowicie o przesłanie: „Nie wolno przejść obojętnie wobec tragedii Szoah"111 z okazji 60. rocznicy wyzwolenia obozu w Auschwitz oraz o orędzie na Wielki Post: „Starość nie musi oznaczać rezygnacji"12. Wspomniane informacje podawane są w działach „kraj” lub "świat" i mają charakter wiadomości czystej bądź skomentowanej. Wzmiankuje się także kilkakrotnie, na podstawie informacji agencji prasowych, o dość napiętych relacjach pomiędzy Watykanem a Hiszpanią ${ }^{13}$. W pierwszym miesiącu 2005 roku ukazało się 18 słownych jednostek prasowych dotyczących Papieża.

Problemem dla „Rzeczpospolitej”, jak zresztą dla wszystkich poważnych mediów, był sposób informowania o cierpieniu Papieża. Pod kliniką Gemelli największe światowe stacje telewizyjne zbudowały medialne miasteczko, ażeby informować nie tylko o stanie zdrowia Jana Pawła II, ale także po to, aby jako pierwsze podać wiadomość o Jego śmierci ${ }^{14}$. Podobne miasteczko stanęło $\mathrm{w}$ okolicach Watykanu.

Ks. K. Marcyński udzielił dziennikowi wywiadu Papież nie schodzi z $k r z y \dot{z} a^{15}$, w którym przedstawia różnice, jakie zachodzą pomiędzy patrzeniem na chorobę Papieża z perspektywy wiary a opisywaniem jej przez środki społecznego przekazu. Dla ludzi wierzących choroba Papieża, jak każde zresztą cierpienie, jest raczej pewnym misterium, które należy kontemplować i któremu towarzyszy modlitwa, a nie wydarzeniem czy zjawiskiem, które można by sfilmować lub sfotografować. Poza tym, z racji urzędu i misji, jaką pełnił Jan Paweł II, również Jego choroba i powolne odejście były formą katechezy i kazania, które Papież wygłosił współczesnemu człowiekowi bez słów. Dlatego też media, którymi posługiwał się Jan Paweł II w ewangelizacji, które przez cały pontyfikat in-

${ }^{10}$ Zob. E. Czaczkowska, Papież nie przyjedzie do Polski, „Rz” 2005, nr 10, s. 1, 4.

${ }^{11}$ Zob. "Rz" 2005, nr 23, s. 3.

12 Zob. J. Moskwa, tamże, s. 8.

${ }^{13}$ Zob. E. Czaczkowska, Zgoda na prezerwatywy, "Rz" 2005, nr 16, s. 2; AFP, Watykan o prezerwatywach, „Rz” 2005, nr 17, s. 6; AFP, Papież upomina Hiszpanów, „Rz” 2005, nr 20, s. 5.

${ }^{14}$ Zob. K. Zuchowicz, Dziennikarze koczuja przed klinikg Gemelli, „Rz” 2005, nr 49, s. 7; P. Kowalczuk, Goraczka medialna, tamże.

${ }^{15}$ Zob. „Rz” 2005, nr 50, s. 6. Wywiad przeprowadziła E. Czaczkowska. 
formowały o Jego działalności i analizowały Jego nauczanie, towarzyszyfy $w$ chwilach Jego cierpienia i umierania, realizując swoją misję. Zadaniem odbiorcy mass mediów jest niejako przebicie się przez „wizualno-informacyjne bariery", ażeby wejść głębiej w tajemnicę cierpienia ${ }^{16}$. Jako że cierpienie jest trudne do opisania, środki społecznego przekazu nie są $\mathrm{w}$ stanie oddać tajemnicy cierpienia, mogą jednak pomóc ludziom $\mathrm{w}$ towarzyszeniu choremu i współczuciu mu. Polskie gazety, w tym także „Rzeczpospolita”, informując o chorobie Papieża, generalnie pisały o cierpieniu nie tyle Głowy Kościoła czy osoby publicznej, ale o cierpieniu kogoś bliskiego. Czyniły to ze współczuciem, szanując godność i prywatność. „Grzechem”, jak twierdzi E. Czaczkowska, było niejednokrotnie zbyt optymistyczne przedstawianie stanu zdrowia Jana Pawła II. Graniczyło to czasami z podawaniem wiadomości niesprawdzonych, a nawet plotek. Zachodnie media wykazywały mniej taktu. Zdarzyło się nawet, co prawda przez pomyłkę, że na stronie internetowej szwedzkiej telewizji SVT już na początku marca ukazała się informacja o śmierci Papieża ${ }^{17}$.

W lutym opublikowano 37 słownych jednostek prasowych odnoszących się bezpośrednio lub pośrednio do stanu zdrowia Papieża. Były to przede wszystkim informacje o pobytach Jana Pawła II w szpitalu, o Jego chorobach, działaniach lekarzy, modlitwie wiernych za Jego zdrowie, a także o pewnej blokadzie informacyjnej dotyczącej prawdziwego stanu zdrowia Ojca św. Ukazywały się one przede wszystkim w działach „świat”, „kraj” oraz „w rzeczy samej” (strona 2). Pod koniec lutego od 48 numeru utworzono specjalny dział "Jan Paweł II", który, choć nie systematycznie, ukazywał się aż do śmierci i pogrzebu Papieża Polaka.

Już pierwszego lutego podano informację agencyjną, iż została odwołana audiencja generalna $z$ powodu grypy Papieża ${ }^{18}$. Ojciec św. po raz pierwszy w 2005 roku został hospitalizowany. W następnych dniach ukazywały się informacje o poprawie zdrowia Jana Pawła II oraz o modlitwach w Jego intencji ${ }^{19}$. W Środę Popielcową Papież przebywał jeszcze w klinice Gemelli ${ }^{20}$, ale już w czwartek wieczorem wrócił do Watykanu.

16 Zob. tamże.

17 Zob. E. Czaczkowska, Jak pisać o cierpiącym papieżu, „Rz” 2005, nr 56, s. 2.

18 Zob. MT-O, AFP, KAI, Papież ma grype, „Rz” 2005, nr 26, s. 7.

19 Zob. J. Moskwa, Stan zdrowia Jana Pawta II się poprawia, „Rz” 2005, nr 28, s. 7; J. Sad., Polska modli się za Papieża, "Rz” tamże; MT-O, AFP, KAI, PAP, Jan Paweł II dochodzi do zdrowia, "Rz” 2005, nr 29, s. 7; K.Z., Papież czuje się lepiej, „Rz” 2005, nr 30, s. 15; SP, PAP, AFP, Reuters, Aniot Pański z Papieżem, "Rz" 2005, nr 31, s. 1, 6.

20 Zob. PAP, Środa popielcowa bez Papieża, "Rz" 2005, nr 34, s. 8. 
Wcześniejsze dolegliwości: grypa, zapalenie krtani i tchawicy ustąpiły ${ }^{21}$. Podczas modlitwy na Anioł Pański Jan Paweł II osobiście podziękował za modlitwy $\mathrm{w}$ Jego intencji ${ }^{22}$. Szybko wracał do zdrowia i zaczął przemawiać do wiernych, czym zaskoczył lekarzy ${ }^{23}$. Uspokoiło to nieco atmosferę wokół Jego stanu zdrowia. Niestety, nie na długo. Już 25 lutego „Rzeczpospolita" informuje, iż Jan Paweł II ponownie znalazł się w szpitalu $\mathrm{z}$ powodu nawrotu grypy oraz trudności $\mathrm{z}$ oddychaniem. Został poddany zabiegowi tracheotomii ${ }^{24}$. W ostatnich dniach lutego na lamach gazety ukazywały się $\mathrm{w}$ informacje i spekulacje dotyczące faktycznego stanu zdrowia Papieża. Odnotowywano także różne reakcje na to, co wydarzyło się w Rzymie. Informowano, że Ojciec św. ukazał się w oknie kliniki, relacjonowano modlitwy katolików, prawosławnych i żydów w Jego intencji. Nie tylko w Polsce, ale w całym świecie dała się zauważyć swoista „medialna gorączka" związana z papieską chorobą. Wszystkie najpoważniejsze światowe agencje informacyjne, telewizje, prasa oddelegowały swoich dziennikarzy i reporterów w celu informowania o chorobie Jana Pawła $\mathrm{II}^{25}$. I tak pozostało aż do jego śmierci i pogrzebu.

W marcu ukazały się w „Rzeczpospolitej” 33 słowne jednostki prasowe związane $\mathrm{z}$ osobą Jana Pawła II. Zamieszczano je przede wszystkim, podobnie jak w lutym, w działach: „świat” i „kraj”, rzadziej w dziale „W rzeczy samej” czy „opinie”. Częściej natomiast wiadomości te przedstawiano bądź sygnalizowano na stronie pierwszej. Były to informacje zarówno agencyjne, jak i własne. Tematyka w dalszym ciągu ogniskowała się wokół stanu zdrowia Papieża. Na początku marca opisywano, czym jest zabieg tracheotomii, któremu został poddany Papież i na czym polega rehabilitacja. Wspomniano także zamieszanie, jakie wywołał ponowny pobyt Jana Pawła II w szpitalu. W dalszym ciągu spekulowano na temat

${ }^{21}$ Zob. J. Moskwa, Papież znowu w Watykanie, „Rz” 2005, nr 35, s. 9.

${ }^{22}$ Zob. tenże, Papież dziękuje za modlitwy, „Rz” 2005, nr 37, s. 7.

${ }^{23}$ Zob. AP, PAP, Papież zaskoczyt lekarzy, "Rz” 2005, nr 40, s. 7; J. Moskwa, Papież znowu przemawia do wiernych, „Rz" 2005, nr 43, s. 1, 9; tenże, Jan Pawet II na telebimie, "Rz” 2005, nr 46, s. 7.

${ }^{24}$ Zob. E. Czaczkowska, J. Moskwa, Modlitwa o zdrowie Papieża, „Rz” 2005, nr 47, s. 1; J. Moskwa, E. Czaczkowska, Jan Pawet II znowu w szpitalu, tamże, s. 7; P.Z., Choroba Ojca św., tamże.

${ }^{25}$ Zob. Ojcze nasz za Jana Pawta II, „Rz” 2005, nr 48, s. 1; J. Moskwa, E. Czaczkowska, Ojciec św. nabiera sit, tamże, s. 3; E. Czaczkowska, Pracujemy tak, jakby się nic nie stało. Wywiad $z$ ks. Ptasznikiem, tamże; J. Moskwa, Bez zastępcy, tamże; MT-O, AFP, W dobrych rękach, tamże; J. Sadecki, Podhale śpiewa dla papieża, tamże; T.T.S., AFP, PAP, Świat modli się $i$ wspótczuje, tamże; $W$ prasie światowej, tamże. 
Jego faktycznego stanu zdrowia, różnorodnych diagnoz medycznych, krytykowano sposób przekazywania wiadomości przez służby informacyjne Stolicy Apostolskiej, szczególnie rzecznika prasowego. Podnoszono także wiernych na duchu, informując, że Papież pobłogosławił z okna szpitalnego, że wraca do sił, że ćwiczy mowę i oddech i że Święta Wielkanocne będzie przeżywał w Watykanie, choć przewodniczenie głównym celebracjom Triduum Paschalnego zostało powierzone kardynałom. Ojciec św. ma natomiast udzielić błogosławieństwa Urbi et orbi ${ }^{26}$. Nowością był także sposób celebrowania modlitwy Anioł Pański. Rozważanie na placu św. Piotra odczytywał abp L. Sandri, zaś Ojca św. przebywającego w szpitalu, można było obserwować na telebimie, i On też na zakończenie udzielał błogosławieństwa ${ }^{27}$.

W poniedziałek 14 marca poinformowano, iż Papież wrócił w niedzielę 13 marca wieczorem do Watykanu, gdzie kontynuuje rekonwalescencję. W związku z chorobą jednak musiał ograniczyć swoje spotkania $\mathrm{z}$ wiernymi ${ }^{28}$. Od tego momentu informacje o stanie zdrowia Jana Pawła II nabierają swoistego dramatyzmu. Coraz mniej w nich nadziei na wyzdrowienie. Już same tytuły, które w publicystyce prasowej odgrywają istotną rolę i najbardziej oddają atmosferę drugiej połowy marca, sugerują, iż sytuacja jest bardzo poważna (Minuta dla wiernych ${ }^{29}$, Papież czuje się gorzej30, Papież uśmiecha się, choć cierpi ${ }^{31}$, Papież obecny duchem ${ }^{32}$, Droga Krzyżowa Papieża ${ }^{33}$, Błogostawieństwo bez stów ${ }^{34}$, Papież bardzo chciat mówićc35 czy Milcze-

${ }^{26}$ Zob. J. Moskwa, E. Czaczkowska, Ojciec Święty próbuje mówić, „Rz” 2005, nr 50, s. 6; J. Moskwa, E. Czaczkowska, Papież rozmawiat z kardynatem, „Rz“ 2005, nr 51, s. 5; J. Moskwa, Papież chce szybko opuścić szpital, "Rz” 2005, nr 53, s. 8; MT-O, AFP, PAP, Papież pobłogostawi pielgrzymów, „Rz” 2005, nr 54, s. 13; J. Moskwa, Błogostawieństwo z okna kliniki Gemelli, "Rz" 2005, nr 55, s. 1, 5; MT-O, AFP, PAP, Papież wróci do Watykanu na Wielki Tydzień, „Rz" 2005, nr 56, s. 7; J. Moskwa, Wielkanoc w Watykanie, „Rz" 2005, nr 57, s. 7; tenże, Jan Pawet II może mówić, "Rz” 2005, nr 58, s. 6; tenże, Papież zostanie w szpitalu jeszcze kilka dni, „Rz” 2005, nr 59, s. 7 .

${ }^{27}$ Zob. J. Moskwa, Btogostawieństwo z okna kliniki Gemelli, „Rz” 2005, nr 55, s. 1, 5.

${ }^{28}$ Zob. J. Moskwa, Jan Pawet II opuścit szpital, "Rz" 2005, nr 61, s. 6; tenże, Papież już $w$ Watykanie, tamże, s. 1.

${ }^{29}$ Zob. "Rz" 2005, nr 64, s. 8.

${ }^{30}$ Zob. J. Moskwa, „Rz” 2005, nr 68, s. 5.

${ }^{31}$ Zob. tenże, „Rz” 2005, nr 70, s. 1, 6.

${ }^{32}$ Zob. tenże, „Rz” 2005, nr 71, s. 7.

${ }^{33}$ Zob. tenże, "Rz" 2005, nr 72, s. 1.

${ }^{34}$ Zob. "Rz" 2005, nr 73, s. 1.

${ }^{35}$ Zob. J. Moskwa, tamże, s. 6. 
$\left.n i e^{36}\right)$. Z bólem i wzruszeniem relacjonowane są kolejne próby, jakie podejmował chory Jan Paweł II, ażeby przemówić do wiernych z okna Pałacu Apostolskiego czy to z okazji audiencji generalnych, czy modlitwy na Anioł Pański, czy też z okazji błogosławieństwa Urbi et orbi. W dalszym ciągu narastały spekulacje na temat prawdziwego stanu zdrowia Papieża, spowodowane swoistym embargiem na tego typu informacje ze strony ludzi znajdujących się w najbliższym otoczeniem Ojca św. Poddawano także w wątpliwość możliwości kierowania Kościołem przez chorego Jana Pawła II i w związku z tym oczekiwano Jego ustąpienia. Przypuszczenia te były jednakże dementowane przez wysokich dostojników kościelnych, na przykład przez kardynała J. Ratzingera. „Rzeczpospolita” na swoich łamach zaprezentowała wyrywkowy przegląd prasy europejskiej, zajmującej się analizą aktualnej sytuacji Kościoła w czasie trwania choroby Papieża („Le Monde" czy "Corriere della Sera"). Wiadomości z ostatnich dni marca zorientowane były wokół pogarszającego się stanu zdrowia Papieża, możliwości wykonywania przez Niego urzędu, stanu samego Kościoła, dotyczyły także wpływów polskich duchownych w Watykanie ${ }^{37}$.

\section{2. ŚMIERĆ I POGRZEB JANA PAWŁA II}

W kwietniu ukazały się dwa numery (wydania ogólnopolskie) poświęcone w całości Janowi Pawłowi II: z 4 kwietnia - nr 78 oraz z 9-10 kwietnia - nr 83. Dodatkowo ukazał się numer specjalny 3 kwietnia, w którym zaprezentowano fotoreportaż z 8 pielgrzymek Jana Pawła II do Polski oraz zdjęcia i relacje z 2 kwietnia, czyli dnia śmierci Papieża.

Cechą charakterystyczną kwietniowych jednostek prasowych jest to, iż obok informacji z ostatnich chwil życia Ojca św., faktu samej śmierci i relacji z przygotowania i przebiegu pogrzebu znaczną część zajmują opinie na temat samej osoby Papieża, Jego działalności podczas długiego pontyfikatu, wpływu na życie i działalność Kościoła, na dzieje świata, Europy i Polski. Przedrukowywane bądź streszczane są także teksty z największych i najbardziej opiniotwórczych gazet. Zamieszczane są zarówno wypowiedzi ludzi Kościoła - duchownych i świeckich, jak i polityków, naukowców, artystów, publicystów, którzy nie utożsamiają się z Kościołem.

${ }^{36}$ Zob. P. Kowalczuk, tamże.

${ }^{37}$ Zob. J. Moskwa, Zdrowie i wtadze papieża, "Rz" 2005, nr 74, s. 6; O zdrowiu papieża i stanie Kościoła, „Rz” 2005, nr 75, s. 2; J. Moskwa, Kolejne błogosławieństwo bez słów, tamże, s. 5; tenże, Polska mafia $i$ zachodnie kwasy, tamże. 
Wszystkie te materiały ukazywały się w działach: „świat”, „kraj” bądź w specjalnie poświeconym osobie Jana Pawła II.

Informacje i artykuły „Rzeczpospolitej” z dnia 1 oraz 2-3 kwietnia w sposób wyraźny dawały do zrozumienia, iż życie ziemskie Jana Pawła II dobiega końca. J. Moskwa w relacji z Rzymu zatytułowanej Jan Pawet II nigdy nie ustapi, powołując się na znanego publicystę i pisarza V. Messoriego, stwierdził, że Papież do końca będzie sprawował swój urząd. $\mathrm{W}$ ten sposób uciął spekulacje dotyczące dymisji Ojca św..$^{38}$. W podobnym duchu wypowiedział się G. Weigel - biograf Jana Pawła II, który w artykule Nauki ze schyłku pontyfikatu ukazał, iż cierpienie Ojca św. ma sens i jest dopełnieniem Jego bardzo aktywnej działalności pasterskiej. Jest to tym bardziej ważne, iż współczesna kultura zachodnia nie zajmuje się problemem cierpienia, wręcz go unika. Zgoda na cierpienie, jego akceptacja jest czymś obcym. A przecież przyjęcie na siebie cierpienia jako wyraz posłuszeństwa woli Boga, to istota chrześcijaństwa. Właśnie Chrystus przyjął cierpienie jako swoje powołanie, jako swoje przeznaczenie, dokonując Odkupienia. I Jan Paweł II, jako wierny uczeń Chrystusa, całkowicie oddany swojemu Zbawicielowi, dał świadectwo prawdzie, że cierpienie przyjmowane z pokorą i miłością oznacza współuczestnictwo w Odkupieniu. G. Weigel cytuje kardynała F. Arinze, który uważa, iż Papież ze swego szpitalnego łóżka przekazuje światu istotne pytania dotyczące znaczenia cierpienia, takie jak: czy ma ono sens, czy jest absurdem, czy cierpienie wnosi coś do życia ludzkiego, czy w starości jest godność? Jan Paweł II przeżywając swoją drogę krzyżową daje odpowiedź na te pytania. Cierpienie ma sens i może nas czegoś nauczyć. Współczucie uszlachetnia. Papież przypomina, że nie my jesteśmy panami własnego życia. Poza tym chory Papież budzi nadzieję wśród ludzi starych, chorych, niesprawnych. Choć świat patrzy na Jana Pawła II przez pryzmat polityki, jako na jednego z najważniejszych aktorów sceny politycznej, to jednak jest on przede wszystkim Pasterzem Kościoła Powszechnego, który do końca chce nam przekazywać przesłanie płynące z krzyża, z Wielkiego Piątku i Zmartwychwstania. I za to powinniśmy być Mu wdzięczni ${ }^{39}$.

Jan Paweł II umarł w sobotę 2 kwietnia o godz. 21.37. Wydanie sobotnio-niedzielne „Rzeczpospolitej” z 2-3 kwietnia nie zawierało ostatecznej informacji o śmierci Papieża, niemniej wiadomości o stanie zdro-

${ }^{38}$ Zob. "Rz" 2005, nr 76, s. 6.

${ }^{39}$ Zob. G. Weigel, Nauki ze schytku pontyfikatu, "Rz" 2005, nr 76, s. 11. 
wia Jana Pawła II nie dawały żadnej nadziei na poprawę. J. Moskwa w relacji z Rzymu pt. Ojciec Święty blisko Boga umieszczonej na pierwszej stronie informował o dramatycznym pogorszeniu stanu zdrowia. Cytował kardynała C. Ruini, iż „Ojciec Święty jest coraz bliżej Boga”, zaś arcybiskup A. Comastri, który przewodniczył w piątek 1 kwietnia wieczornej modlitwie różańcowej, powiedział: „Tego wieczoru lub tej nocy Chrystus otworzy drzwi Papieżowi". Rzecznik prasowy Watykanu J. Navarro-Valls podczas podawania komunikatu płakał, mówiąc, że jeszcze nie widział Ojca Świętego w tak złym stanie. Zaś przyjaciel Papieża kardynał A. M. Deskur powiedział, iż „Jan Paweł II gaśnie pogodnie”. Na placu św. Piotra, a także $\mathrm{w}$ wielu miejscach $\mathrm{w}$ Polsce i na całym świecie, gromadziły się tłumy wiernych, modlących się $\mathrm{w}$ intencji Papieża ${ }^{40}$. Dopełnieniem wiadomości o Jego dramatycznym stanie zdrowia jest rozszerzona informacja tego samego autora pt.: Najważniejsze przestanie. Korespondent rzymski „Rzeczpospolitej” stwierdza, iż dniami tragicznymi dla Jana Pawła II były Niedziela Wielkanocna i środa w oktawie wielkanocnej, kiedy to dwukrotnie próbował przemówić do wiernych na placu św. Piotra i dwukrotnie nie mógł wydobyć głosu. On, który był sługą Słowa nie mógł wypowiedzieć żadnego słowa do zgromadzonych wiernych ${ }^{41}$.

Arcybiskup J. Życiński w artykule pt. Ostatni list pasterskit ${ }^{42}$ stwierdza, że przesłaniem ostatnich dni życia Papieża jest Jego „pożegnalny list apostolski pisany językiem miłości wyrażanej w tajemnicy krzyża". Ma to szczególną moc świadectwa, tym bardziej, że nasza cywilizacja unika programowo trudnych tematów dotyczących cierpienia i wierności. W tym „pożegnalnym liście” każde słowo i każdy gest jest świadectwem wiary i więzi z Bogiem. Istotą postawy wiary jest ufne zjednoczenie z Panem Bogiem w najtrudniejszych sytuacjach. A dojrzałość wiary chrześcijańskiej ukazuje się właśnie w stylu przyjmowania krzyża. Wzór tego pozostawia nam odchodzący do domu Ojca Jan Paweł II. Naszą dojrzałą odpowiedzią na "ostatni list papieski” jest przejście w tych dniach przez trudny egzamin $\mathrm{z}$ wiary oraz ufna solidarność $\mathrm{w}$ godzinie krzyża.

${ }^{40}$ Zob. J. Moskwa, Ojciec Święty blisko Boga, „Rz” 2005, nr 77, s. 1; P. Kowalczuk, Stacje Ojca Świętego, tamże, s. 2; J. Matusz, Wadowice proszq o cud, tamże, s. 3; I. Trusewicz, Byliśmy dumni, że nas odwiedzit, tamże s. 3; J. Góra, Polska się modli, tamże, s. 3; K.Z., Świat modli się i płacze, tamże, s. 4; R. Mickiewicz, Przypomniat o litewskim Kościele, tamże, s. 4; P. Reszka, Smutny Kościót na Małej Gruzińskiej, tamże, s. 4.

${ }^{41}$ Zob. „Rz" 2005, nr 77, s. 2.

${ }^{42}$ Zob. J. Życiński, Ostatni list pasterski, „Rz” 2005, nr 77, s. 2. 
Numer 78 „Rzeczpospolitej” z 4 kwietnia w całości został poświęcony Janowi Pawłowi $\mathrm{II}^{43}$. Pierwsza strona na czarnym tle przedstawia profil twarzy Papieża oraz tekst podpisany przez Zespół „Rzeczpospolitej" pt. Żegnaj Ojcze. Na stronie piątej w artykule pt. Byteś dla nas darem Bożego Miłosierdzia podpisanym przez dziennikarzy „Rzeczpospolitej” opisane są reakcje rodaków na wieść o śmierci Jana Pawła II, o Mszy św. $\mathrm{w}$ Warszawie i w Łagiewnikach ${ }^{44}$. W podobnym tonie, podpisanym przez korespondentów „Rzeczpospolitej”, utrzymany jest tekst pt. Zawsze będziemy Cię kochać, Ojcze Święty ${ }^{45}$. W Polsce do dnia pogrzebu ogłoszono żałobę narodową. Poza tym na łamach gazety znajdują się obok informacji korespondentów czy agencji prasowych dotyczących śmierci Ojca św. oraz reakcji świata na to wydarzenie, także wypowiedzi i wywiady z ludźmi Kościoła, polityki, nauki i kultury. Pojawiają się również próby podsumowania pontyfikatu Papieża Polaka. Drukowane są także fragmenty Autobiografii Jana Pawła II oraz książki J. Moskwy pt. Świat Karola Wojtyły, a także nekrologi. W dziale "sport” S. Szczepłek ukazał zainteresowania sportowe Papieża-Polaka, który był kibicem "Cracovii"46.

Ostatni dzień życia Jana Pawła II zrekonstruował J. Moskwa w artykule $\mathrm{Na}$ wieczny odpoczynek. Do ostatnich chwil życia towarzyszyło Papieżowi najbliższe otoczenie: osobiści sekretarze (abp St. Dziwisz, ks. M. Mokrzycki), polscy księża (kardynał M. Jaworski, abp St. Ryłko, ks. T. Styczeń), siostry zakonne, lekarze i pielęgniarze. Odwiedzili Go także hierarchowie watykańscy. Jeden z lekarzy ujawnił, iż zespół opiekujący się Ojcem Świętym zrobił wszystko, by uratować Jego życie, ale nie stosował tak zwanej uporczywej terapii, aby nie przysparzać dodatkowych cierpień fizycznych i psychicznych. Po śmierci do pokoju weszli kardynałowie: sekretarz stanu A. Sodano i kamerling E. M. Somalo ze swoimi zastępcami: abp. L. Sandrim i abp. P. Sardim. Nieco później dołączyli dziekan Kolegium Kardynalskiego kardynał J. Ratzinger i kardynał J. Tomko. W ich obecności, zgodnie z rytuałem, kardynał kamerling rozpoznał zmarłego, zdjął Mu z ręki Pierścień Rybaka i polecił zniszczyć go wraz z pieczęciami. W tym czasie na placu św. Piotra ludzie gromadzili się na modlitwie ${ }^{47}$.

${ }^{43}$ Na stronie osiemnastej w dziale „świat” podano kilka informacji niezwiązanych z osobą Jana Pawła II.

${ }^{44}$ Zob. "Rz" 2005, nr 78, s. 5.

${ }^{45}$ Zob. tamże, s. 7.

${ }^{46}$ Zob. S. Szczepłek, Lubił grać na bramce, "Rz" 2005, nr 78, s. 19.

47 Zob. J. Moskwa, Na wieczny odpoczynek, „Rz” 2005, nr 78, s. 2. 
Śmierć Papieża odbiła się szerokim echem w całym świecie, czego przykładem jest choćby ogłoszona $\mathrm{w}$ kilkunastu krajach żałoba narodo$\mathrm{wa}^{48}$ oraz cytowane fragmenty z prasy światowej. „Le Monde” nazywa Ojca Świętego Karolem „Wielkim”, który przyczynił się do upadku muru berlińskiego i zdecydowanie działał na rzecz praw człowieka. „Los Angeles Times" w artykule Chciat nawrócić świat na humanizm chrześcijański stwierdza, że według nauczania Jana Pawła II fundamentem moralnym każdego wolnego społeczeństwa jest godność osoby ludzkiej. "Corriere della Sera” nazywa Go „Papieżem dialogu”. „The Independent” stwierdza, że Jan Paweł II choć konserwatywny, był jednak kompas moralny, według którego każdy może określić swoje położenie. „The Observer” uważa, że Papież był "Człowiekiem XX wieku”, który kochał ludzkość, a w Watykanie tchnął nowe życie. To wszystko sprawiło, jak napisała „la Repubblica", że jego śmierć stała się wydarzeniem światowym, które wszystkie inne sprawy zepchnęło $\mathrm{w}$ cieńn ${ }^{49}$.

Papieska śmierć rzeczywiście stała się wydarzeniem o zasięgu światowym, wykraczającym poza świat katolicki czy nawet chrześcijański. Na ten temat wypowiadali się przywódcy państw i politycy, akcentując przede wszystkim rolę polityczną i społeczną zmarłego Papieża. Prezydent Stanów Zjednoczonych G. W. Bush stwierdził, że świat utracił obrońcę wolności. Przewodniczący Komisji Europejskiej J. M. Barroso, oddając cześć Papieżowi, powiedział, że odegrał on istotną rolę w zjednoczeniu Europy oraz w rozwoju idei wolności i demokracji. Premier Wielkiej Brytanii T. Blair oświadczył, że w osobie Jana Pawła II świat stracił przywódcę religijnego, poważanego przez ludzi wszystkich wyznań. Kanclerz Niemiec G. Schrőder podkreślił, że Papież swym oddziaływaniem i swą osobowością zmienił świat. Prezydent Francji J. Chirac w imieniu swojego kraju złożył hołd niestrudzonemu pielgrzymowi dialogu, pojednania i pokoju. Prezydent Rosji W. Putin powiedział, że służba Papieża skierowana była na budowę bardziej sprawiedliwych stosunków międzynarodowych. Prezydent Czech V. Klaus w specjalnym oświadczeniu napisał, że Jan Paweł II był mądrym i wrażliwym człowiekiem, który całe życie poświęcił idei miłości do człowieka a także idei ludzkiej wolności, godności i odpowiedzialności. Prezydent Austrii H. Fischer nazwał Ojca Świętego największym autorytetem moralnym na świecie. Prezydent Litwy V. Adamkus stwierdził, że świat stracił jedną z najwybitniejszych postaci naszych

${ }^{48}$ Zob. T.T.S., AFP, Żałoba narodowa w kilkunastu krajach, „Rz” 2005, nr 78, s. 3.

${ }^{49}$ Zob. T.T.S, „Rz” 2005, nr 78, s. 3. 
czasów. Prezydent Ukrainy W. Juszczenko nazwał Papieża „Wielkim Człowiekiem" i stwierdzil, że na zawsze w pamięci pozostanie jego jasny obraz. Prezydent Białorusi A. Łukaszenko podkreślił, że odejście Jana Pawła II jest wielką stratą dla wszystkich ludzi dobrej woli. Premier Izraela A. Szaron nazwał Papieża wielkim człowiekiem pokoju i prawdziwym przyjacielem narodu żydowskiego. Prezydent Iranu M. Chatami w przesłanej kondolencji do Watykanu nazwał Papieża obrońcą prawdy, sprawiedliwości i pokoju. Żal i kondolencje przesłały także m.in. władze Kuby i Chin ${ }^{50}$. W wypowiedziach tych dominował raczej aspekt poza religijnej działalności Jana Pawła II, a także podziw dla jego bogatej osobowości. Również przedstawiciele różnych religii, wyznań i obrządków chrześcijańskich z całego świata łączyli się w żałobie i modlitwie po śmierci Ojca Świętego. W oficjalnych wypowiedziach akcentowano przede wszystkim ekumeniczny wymiar posługi papieskiej ${ }^{51}$.

Obok gatunków informacyjnych na łamach 78 numeru „Rzeczpospolitej" drukowano także gatunki o charakterze opiniotwórczym. Ukazywały się komentarze, opinie, wywiady, które próbowały dokonać oceny i bilansu bądź to samej osoby Papieża, bądź Jego działalności, a także oceny stanu Kościoła i świata po tak długim pontyfikacie. Abp J. Michalik w wywiadzie dla E. Czaczkowskiej scharakteryzował osobę Ojca Świętego, podkreślając, że był głodny człowieka, kochał ludzi. Dla niego każdy człowiek był obrazem Boga, dlatego tak bronił każdego człowieka od poczęcia do naturalnej śmierci. Jego wielkość oparta jest na fundamencie ogromnej wiary i miłości do konkretnego człowieka ${ }^{52}$. Osobiste wspomnienia ze spotkań z Papieżem przedstawił pierwszy niekomunistyczny premier Polski T. Mazowiecki ${ }^{53}$, a także znakomity aktor G. Holoubek ${ }^{54}$. Krótkimi refleksjami po śmierci Papieża podzielili się fizyk prof. Ł. Turski oraz abp J. Życiński. Ten pierwszy, chociaż - jak sam przyznaje - będąc z ze-

50 Zob. R. Mic, Pielgrzym dialogu i pojednania, „Rz” 2005, nr 78, s. 3; A. Klugman, Papież narodu żydowskiego, "Rz" 2005, nr 78, s. 3; P. Reszka, Spóźniony żal rosyjskiej Cerkwi, „Rz" 2005, nr 78, s. 4; P. Gillert, John Paul II Superstar, „Rz” 2005, nr 78, s. 4.

${ }^{51}$ Zob. R. Mic, Pielgrzym pokoju i pojednania, „Rz” 2005, nr 78, s. 3; A. Klugman, Papież narodu żydowskiego, „Rz” 2005, nr 78, s. 3; P. Reszka, Spóźniony żal rosyjskiej Cerkwi, „Rzepa” 2005, nr 78, s. 4; P. Gillert, John Paul II Superstar, „Rz” 2005, nr 78, s. 4; E. Południk, Grekokatolicy nie zapomna papieża, „Rz” 2005, nr 78, s. 7.

${ }^{52}$ Zob. Byt głodny cztowieka, „Rz” 2005, nr 78, s. 2.

${ }^{53}$ Zob. M. Subotić, I tak sobie myśle, co dalej (Rozmowa z T. Mazowieckim), „Rz” 2005, nr 78 , s. 8

${ }^{54}$ Zob. G. Holoubek, Optymistyczne przestanie, „Rz” 2005, nr 78, s. 8. 
wnątrz Kościoła, w dniu śmierci Jana Pawła II odczuł, że „straciliśmy chyba jedyny punkt $\mathrm{w}$ tym moralnym systemie kosmicznej nawigacji, pozwalający nam na znalezienie swojego kursu przez życie"55. Metropolita lubelski w swoim tekście stwierdza, że Ojciec Święty, który cały należał do Boga w myśl swojej biskupiej dewizy „Totus Tuus”, był Bożym darem dla naszego pokolenia $\mathrm{w}$ okresie wyjątkowych przemian. Pozostawił nam duchowy testament, abyśmy nie podcinali korzeni, z których wyrastamy oraz kształtowali naszą pamięć i tożsamość ${ }^{56}$.

W artykule pt. Pielgrzym u kresu drogi B. Luft napisał, że Jan Paweł II odważnie szedł na spotkanie świata i ludzi. Jeśli chodzi o system wartości to był konserwatystą, jednak ów konserwatyzm nie miał charakteru obronnego, odruchu zamykania się w oblężonej twierdzy. Papież był ofensywny. Swoją posługę rozumiał jako formę ojcostwa. Słowem i własnym świadectwem starał się ludziom otwierać drogę do wiary w Boga. Wszystko inne było konsekwencją tego zadania, czy to w wymiarze moralnym, społecznym czy politycznym. „Nasz świat byłby gorszy, gdyby Go nie było" ${ }^{\prime \prime}$.

Charakteryzując postać Jana Pawła II, J. Wocial stwierdził, że całe Jego życie i cała twórczość: naukowa, literacka i duszpasterska - stanowią jedność. I nie jest to tylko jedność, która przejawia się $\mathrm{w}$ harmonii życia osobistego, sposobu sprawowania urzędu i głoszonej nauki. Jest to jedność w znaczeniu teologicznym, tzn. Namiestnik Chrystusa pozostawał w jedności z Tym, którego głosił. To, co Papież swoją obecnością wyraża i przekazuje, jest obrazem Słowa. „Słowo Boże, gdy zostaje przyjęte, staje się żywą tkanką człowieka, przenika całą jego egzystencję. Nie jest już słownym przekazem, lecz Słowem wcielonym w konkret: żywą jedność woli, umysłu, ducha i ciała" ${ }^{\prime 58}$.

Papieskie cierpienie stało się tematem artykułów wybitnego lekarza prof. A. Szczeklika oraz E. Czaczkowskiej. O ile redaktor Czaczkowska skupiła się raczej na przypomnieniu dolegliwości i chorób, jakie na przestrzeni swojego pontyfikatu przeżył Jan Paweł $\mathrm{II}^{59}$, o tyle prof. A. Szczeklik przedstawił refleksję na temat cierpienia. Autor ukazał, iż najpierw Papież nauczał o cierpieniu, ukazując jego zbawczy sens. Z czasem Ojciec

\footnotetext{
${ }^{55}$ Ł. A. Turski, Utracony punkt, „Rz” 2005, nr 78, s. 8.

${ }^{56}$ Zob. J. Życiński, Duchowy testament, „Rz” 2005, nr 78, s. 8.

${ }^{57}$ Zob. B. Luft, Pielgrzym u kresu drogi, "Rz" 2005, nr 78, s. 11.

${ }^{58}$ J. Wocial, Wezwanie i tożsamość, „Rz” 2005, nr 78, s. 15.

${ }^{59}$ Zob. E. Czaczkowska, Cierpiał na oczach świata, "Rz” 2005, nr 78, s. 12.
} 
Święty nie pisał ani nie mówił o cierpieniu, ale sam stał się cierpieniem. Samym sobą pokazał nam, jak mocą ducha i wiary można cierpienie przezwyciężyć, swoim cierpieniem wzbogacić życie milionów ludzi. Pokazał także, jak należy umierać. Po prostu odsłonił nam tajemnice cierpienia i śmierci ${ }^{60}$. W podobnym duchu wypowiedział się prof. R. Sulima, antropolog kultury. W wywiadzie udzielonym E. Czaczkowskiej stwierdził, iż Jan Paweł II dał świadectwo wielkiej tradycji umierania we wspólnocie, wśród bliskich. Takie umieranie było naturalne w polskiej tradycji, było zawsze jawne, nierzadko pogodne, pełne nadziei. Poza tym ten znany antropolog kultury stara się wyjaśnić fenomen zjednoczenia się Polaków, bez względu na różnice światopoglądowe, wokół cierpiącego i umierającego Papieża. Według niego, było to wielkie zbiorowe doświadczenie sytuacji granicznej. Dla każdego rodaka cierpiący Ojciec Święty był tym drugim człowiekiem, przy którym obecność jest uznawana za moralny obowiązek. Odejście Jana Pawła II rozpoczyna nowy czas. Jest znakiem. W umieraniu Papieża doświadczyliśmy odnowienia czasu ${ }^{61}$.

Próbą podsumowania osiągnięć pontyfikatu Papieża-Polaka jest tekst G. Weigla pt. Z wiarq $k u$ wolności ${ }^{62}$. Według amerykańskiego biografa papieskiego, Jan Paweł II pozostawił po sobie 10 trwałych dokonań: dostosował papiestwo do XXI w., poczynił wysiłki na rzecz ochrony dziedzictwa Soboru Watykańskiego II, odegrał kluczową rolę w obaleniu komunizmu, w swoim nauczaniu zaoferował ludzkości wizję wolnego, dobrze prosperującego i czystego moralnie społeczeństwa, wzmógł aktywność ekumeniczną, ożywił stosunki żydowsko-katolickie, otworzył się na ludzi wyznających inne religie, a także na świat nauki i kultury, opublikował Katechizm Kościoła Katolickiego, zaprezentował „teologię ciała” jako chrześcijańską odpowiedź na rewolucję seksualną. Miał także osobisty wpływ na ludzi. W ramach pierwszego i ostatniego dokonania mieści się zapewne nie tylko wzajemna sympatia, ale i miłość pomiędzy Janem Pawłem II a młodzieżą. Zwraca na to uwagę Sz. Hołownia w artykule pt.: Pokolenie JP2. W dniach umierania Papieża tłumy ludzi młodych gromadziły się w kościołach na całym świecie; „posty” w Internecie, esemesy, świeczki - wszystko po to, by być z Nim w chwili Jego śmierci. To był

${ }^{60}$ Zob. A. Szczeklik, Ostatnia pielgrzymka, "Rz" 2005, nr 78, s. 12.

${ }^{61}$ Zob. E. Czaczkowska, Czas na chwile zatrzymany (Wywiad z R. Sulima), "Rz” 2005, nr 78, s. 14 .

${ }^{62}$ Zob. G. Weigel, Z wiarq ku wolności, „Rz” 2005, nr 78, s. 13. Pierwszy raz ten tekst został opublikowany w maju 2003 roku na łamach „Rz”. 
znak, „że młodzi ludzie dobrze odrobili lekcję, którą od samego początku przekazywał Jan Paweł II - że wymagania można stawiać tylko z miłości. Z miłości do kogoś. Do Chrystusa, do drugiego człowieka. Że tablice z przykazaniami można przyjąć z rąk kogoś, kogo naprawdę się kocha"63. Natomiast P. Wojciechowski, prezes Stowarzyszenia Pisarzy Polskich, snuje refleksje dotyczące spuścizny i zadań, jakie pozostawił Papież artystom i twórcom. Ukazał Papieża jako kogoś, kto „miał dar skrótu myślowego”, czego przykładem są takie zwroty, jak: „Przekroczyć próg nadziei”, „Posługa myśli - posługa słowa”, „Wymagać od siebie, nawet gdy nikt od nas nie wymaga”, "Miłość miłosierna - wyobraźnia miłosierdzia". Konkludując, pisarz i reżyser, a także wykładowca łódzkiej szkoły filmowej, stwierdza, iż „Jego dary są naszymi zadaniami, Jego dary stają się pytaniami w naszym rachunku sumienia, Jego dary czekają, aby je odkryć. Czy może tu być czas na zastygnięcie w żałobie? Lepiej uświadomić sobie jeszcze raz - On żyje, to my umieramy. I mamy co robić, nim umrzemy" ${ }^{\prime \prime}$.

Jedna strona gazety została poświęcona informacjom agencyjnym związanym z przeniesieniem ciała Papieża do Bazyliki św. Piotra oraz z przygotowaniem do konklawe ${ }^{65}$.

Na ostatniej stronie numeru 78 „Rzeczpospolitej”, poświęconego w całości Janowi Pawłowi II, redakcja umieściła, obok zdjęcia ceremonii chrztu dzieci w Kaplicy Sykstyńskiej, fragment Tryptyku rzymskiego, który kończy się słowami: „A przecież nie cały umieram, to co we mnie niezniszczalne trwa" ${ }^{\prime 66}$. Słowa te mogą stanowić wręcz lapidarne streszczenie zawartości całego numeru gazety. Autorzy, szczególnie artykułów, starali się ukazać przede wszystkim to, co w działalności i nauczaniu Papieża ma walor ciągle aktualny i stanowi niejako zadanie do wypełnienia.

W następnych dniach łamy „Rzeczpospolitej” zapełniły się informacjami dotyczącymi samego pogrzebu, miejsca pochówku, spodziewanych tłumów w tych dniach $\mathrm{w}$ Rzymie, spekulacjami na temat rychłej beatyfikacji Jana Pawła II, a także reakcjami zarówno Polaków, jak i innych nacji na wieść o śmierci Papieża.

${ }^{63}$ Sz. Hołownia, Pokolenie JP2, „Rz” 2005, nr 78, s. 14.

${ }^{64}$ P. Wojciechowski, On żyje - to my umieramy, "Rz" 2005, nr 78, s. 15.

${ }^{65}$ Zob. Emocje wzięty górę nad tradycja; Jak wybierany jest papież; Kto zostanie 265. biskupem Rzymu, „Rz” 2005, nr 78, s. 6.

${ }^{66}$ Jan Paweł II, Tryptyk rzymski, „Rz” 2005, nr 78, s. 20. 
Spekulowano na temat miejsca pochówku Ojca św. Asumpt ku temu miał dać fragment Testamentu Jana Pawła II, w którym Papież napisał, iż miejsce pogrzebu i pochówku mają uzgodnić kardynałowie, rodacy i biskupi polscy ${ }^{67}$. Wokół tłumaczenia oraz samej publikacji Testamentu powstało pewne zamieszanie, co nie omieszkały uwypuklić światowe media. Ostatecznie miejscem wiecznego spoczynku stała się krypta w Grotach Watykańskich po Janie XXIII ${ }^{68}$.

$\mathrm{Na}$ łamach gazety wypowiadali się przedstawiciele świata nauki, kultury, polityki, Kościoła, a także zwyczajni ludzie. Wypowiedzi te miały najczęściej charakter osobisty i wspomnieniowy ${ }^{69}$.

W numerach 79-82 „Rzeczpospolitej” stworzono dział „Kościół i świat po Janie Pawle II", który był swoistym forum wymiany myśli i refleksji. Poddano wstępnej analizie spuściznę, jaka pozostała po Janie Pawle II, zarówno na płaszczyźnie nauczania jak i działalności pasterskiej. Zwrócono uwagę na to, czego dokonał zmarły Papież, co wymaga kontynuacji a co zmiany, jakie są oczekiwania świata i Kościoła wobec następcy. Opinie te mają raczej charakter pozytywny wobec dokonań Papieża Polaka, choć nie zabrakło także głosów krytycznych ${ }^{70}$. Te ostatnie pochodziły z kręgów tradycjonalistów oraz teologów skonfliktowanych z Urzędem

${ }^{67}$ Zob. Jan Paweł II, Testament, „Rz” 2005, nr 83, s. 2. Nieco zamieszania wprowadziło opóźnienie w opublikowaniu Testamentu, spowodowane tłumaczeniem na inne języki. Sam Testament napisany został $\mathrm{w}$ języku polskim.

${ }^{68}$ Zob. J. Moskwa, Jan Pawet II spocznie obok świętego Piotra, „Rz” 2005, nr 79, s. 1; K. Kowalski, Jan Pawet II spocznie pod bazylika św. Piotra, tamże, s. 2;

${ }^{69}$ Zob. Dziennikarze "Rz”, Jego duch pozostaje z nami, „Rz” 2005, nr 79, s. 3; K. Piesiewicz, Pamiętam oczekiwanie na Niego, tamże s. 3; I. Trusowicz, Przyszedt jak do domu, tamże s. 3; P. Jendroszczyk, Spetniona nadzieja mieszkańców komunistycznego świata (rozmowa $z$ W. Thiersem), tamże s. 5; A. Hall, Nauczyciel patriotyzmu, tamże s. 6; K. Kutz, Para nart, wiosta i książki, tamże, s. 6; A. Łapinki, Czujne, reżyserskie spojrzenia, tamże s. 6; abp St. Dziwisz, Może trzeba byto tej krwi, tamże s. 7; P.Z. J.M., Pomytka czy manipulacja, „Rz" 2005, nr 83, s. 7.

${ }^{70}$ Zob. M. Król, Zrozumieć nakaz mitosierdzia, „Rz” 2005, nr 79, s. 8; J. Rolicki, Bardziej konserwatywny a mniej koncyliarny, tamże, s. 8; A. Libera, Wiek dwudziesty - śmierć Boga, tamże, s. 9; P. Milcarek, Ta nieobecność jest czasem próby, tamże, s. 9; J. Kowalczyk, Dramaturg trudnych pytań, tamże, s. 13; D. Michałowska, Poeta na zawsze, tamże, s. 13; J. Grosfeld, Stowo i czyn, „Rz" 2005, nr 80, s. 7; E. Czaczkowska, Kościót założyt Jezus (rozmowa z A. Effet), tamże, s. 7; P. Jendroszyk, Zabrakło dyskusji (rozmowa z H. Häringem), tamże, s. 7; J. Szajna, Kierowat sie mitosierdziem dla stabych i biednych, tamże, s. 10; S. Krajeński, Ciężar historii, nadzieja braterstwa, „Rz” 2005, nr 81/82, s. 7; Z. Notowski, Nie zostawit nas sierotami, tamże, s. 7; G. Polak, Zadanie na miare dziejów, tamże, s. 8; P. Reszka, Bronimy tych samych wartości (rozmowa z I. Wyżanowem), tamże, s. 8; K. Warlikowski, Nie stuchaliśmy Go, tamże, s. 11; K.Z. MF-O, Papież osoba kontrowersyjna, „Rz" 2005, nr 85, s. 5. 
Nauczycielskim Kościoła. Głosy krytyczne ukazywały się także w następnych numerach gazety. A. Szostkiewicz stwierdził, że zmarły Papież już od początku swego pontyfikatu spotykał się z zarzutami ze strony pewnej części lewicy. Jeden z jej przedstawicieli T. Eagleton, profesor filozofii kultury z Manchester University, dokonał bilansu szkód, jakie miał wyrządzić Jan Paweł II Kościołowi i katolikom. Wśród tych szkód wymienia: zahamowanie reform soborowych, centralizację władzy, zdławienie teologii wyzwolenia, zamknięcie ust dysydentom, doprowadzenie do „zdziecinnienia” Kościołów lokalnych, zakaz używania prezerwatyw w celu zahamowania rozprzestrzeniania się AIDS w Afryce. Głosy krytyki, choć nie tak bezpośredniej, słychać było także ze strony kościelnych tradycjonalistów, którzy mieli za złe Papieżowi, że szedł z duchem czasów na zbyt dalekie kompromisy ${ }^{71}$.

W czasie trwania żałoby tematyka papieska ogniskowała się $\mathrm{w}$ dalszym ciągu wokół podsumowań zakończonego pontyfikatu oraz opisu pogrzebu i szybkiego wyniesienia na ołtarze Jana Pawła II. Głośnym echem odbiła się, uważana za znakomitą, homilia kardynała J. Ratzingera wygłoszona podczas pogrzebu Papieża. Dziekan Kolegium Kardynałów ukazał w niej wierność Karola Wojtyły powołaniu kapłańskiemu, biskupiemu i papieskiemu, co sprowadziło się $\mathrm{w}$ gruncie rzeczy do wierności Jezusowi Chrystusowi i Matce Najświętszej ${ }^{72}$. Podczas uroczystości pogrzebowych wzruszające były zarówno okrzyki wiernych, jak i transparenty z napisem: "Santo subito", domagające się ogłoszenia zmarłego Papieża świętym ${ }^{73}$.

Na łamach „Rzeczpospolitej” w okresie żałoby opublikowano artykuły oraz przeprowadzono wywiady z ludźmi o różnych poglądach politycznych, filozoficznych, religijnych i światopoglądowych. Wszyscy oni określili Jana Pawła II jako postać charyzmatyczną. Włoski filozof i polityk R. Buttiglione stwierdzil, iż polski Papież przekazywał ludziom prawdę moralną, fundamentalne wartości oraz fundamentalne wymagania moralne i czynił to z miłością. Dlatego należy wszystko uczynić, aby jego przesłanie przetrwało ${ }^{74}$. Znany amerykański polityk i politolog polskiego

${ }^{71}$ Zob. A. Szostkiewicz, Ukryta siła Jana Pawta II, „Rz” 2005, nr 84, s. 9; J. Bartyzel, Czas zapaśników Boga, „Rz” 2005, nr 94, s. 11.

${ }^{72}$ Zob. J. Ratzinger, Patrzy z okna Domu Ojca $i$ nam blogosławi, „Rz” 2005, nr 83, s. 3.

${ }^{73}$ Zob. B. Zubowicz, Święty, święty, "Rz" 2005, nr 83, s. 1; Niebo ptacze nad Rzymem, „Rz" 2005, nr 84, s. 1; E.Cz., Przekonanie o świętości i cuda, „Rz” 2005, nr 84, s. 3.

${ }^{74}$ Zob. B. Zubowicz, Przestanie Jana Pawła II musi przetrwać (rozmowa z R. Buttiglione), „Rz" 2005, nr 83, s. 7 . 
pochodzenia Z. Brzeziński, wspominając osobiste spotkania z Janem Pawłem II, stwierdził, iż Ojciec św. miał szczególny wpływ na uduchowienie współczesnego świata ${ }^{75}$. Polski filozof, niegdyś wybitny marksista, L. Kołakowski uważa, iż wielką zasługą Papieża jest to, że z taką siłą utwierdził obecność Kościoła w naszej cywilizacji ${ }^{76}$. S. Bratkowski, dziennikarz, zaznaczył, iż dzieło Jana Pawła II w Kościele nie zostało zamknięte z chwilą jego śmierci. Papież uczył nadziei i ją gruntowal77. Filozof M. Środa, bynajmniej niezwiązana z Kościołem, tak podsumowała zakończony pontyfikat: „Jego życie było impulsem danym kulturze chrześcijańskiej, którego konsekwencje instytucjonalne i duchowe przyjdzie obserwować dopiero następnym pokoleniom. Wzmocnił Kościół jako instytucję i uczynił wyraźniejszymi jego nakazy ${ }^{78}$. Zaś publicysta katolicki B. Cywiński w krótkim artykule pt. Osieroceni pisze: „Ta śmierć znaczy osierocenie. Po pierwsze, dla tych, którzy osobiście znali go i kochali. Po wtóre, dla wszystkich katolików, dla których czasem był prorokiem, a stale - punktem orientacyjnym, wskazującym, gdzie jest jądro Kościoła na ziemi. Po trzecie, dla Polaków, dla których był jedynym autorytetem i jedynym wodzem"79. $\mathrm{W}$ podobnym duchu wypowiedział się rosyjski dziennikarz F. Łukianow, który w osobie Jana Pawła II widział trwały punkt oparcia w zmieniającym się świecie ${ }^{80}$. B. Misztal, profesor Katolickiego Uniwersytetu Ameryki, ukazał jak zróżnicowany był na przestrzeni lat odbiór nauczania Jana Pawła II w społeczeństwie amerykańskim ${ }^{81}$.

Inny autor, P. Skwieciński, ukazując Ojca św. jako gigantyczną osobowość, która do końca swojego życia miała ogromny wpływ na współczesność, pokusił się o stwierdzenie, że za prawdziwy koniec XX wieku należy uznać śmierć wielkiego Papieża ${ }^{82}$. W jakimś stopniu współbrzmi to z twierdzeniem niemieckiej gazety „Die Welt”, która uważa, że dzień pogrzebu (8 kwietnia 2005 roku) jest drugą, obok 11 września 2001 roku, historyczną datą nowego tysiąclecia. „Msza za Jana Pawła II, która poru-

75 Zob. P. Gillert, Czytanie dla papieża (rozmowa z Z. Brzezińskim), „Rz” 2005, nr 83, s. 10.

${ }^{76}$ Zob. L. Kołakowski, Prorok odpowiedzialnej wolności, „Rz” 2005, nr 83, s. 10-13.

77 Zob. S. Bratkowski, Tyle dobrej energii, „Rz” 2005, nr 83, s. 19.

${ }^{78}$ M. Środa, Postać mistyczna, „Rz" 2005, nr 98, s. 13.

79 "Rz" 2005, nr 83, s. 9.

${ }^{80}$ Zob. F. Łukianow, Bez punktu oparcia, „Rz” 2005, nr 83, s. 10.

${ }^{81}$ Zob. P. Gillert, Prawda trudna do przełknięcia (rozmowa z B. Misztalem), „Rz" 2005, nr 83, s. 11; P. Gillert, Śmierć papieża uwidoczniła podziat Ameryki, „Rz” 2005, nr 84, s. 7.

${ }^{82}$ Zob. P. Skwieciński, Prawdziwy koniec XX wieku, „Rz” 2005, nr 84, s. 2. 
szyła miliony ludzi zgromadzonych w Rzymie i miliardy ludzi na świecie, która sprawiła, że w cudownym kręgu placu św. Piotra zebrali się niemal wszyscy przywódcy świata, była bezprzykładnym triumfem ukazującym prawdziwy wymiar religii. Wiara, której renesans nadaje kształt obecnej epoce, z całą mocą ukazała swą pokojową siłę. Mógł to osiągnąć jedynie Kościół katolicki. Udało mu się to, co nie udało się żadnej innej religii czy wyznaniu. Stabilność instytucjonalna Kościoła, jego wiara w moc tajemnicy, umiejętność organizowania ceremonii i podporządkowanie się charyzmatycznemu autorytetowi papieża - dzięki temu Kościół jest zdolny do skupienia całego świata wokół swego przesłania"83. O sile Kościoła świadczy także i to, że dzięki odważnemu stawianiu pewnych kwestii przez Jana Pawła II, takich jak np.: aborcja, eutanazja, małżeństwo, weszły one do świadomości społecznej i stały się przedmiotem powszechnego dyskursu $^{84}$. Redaktor A. Szostkiewicz twierdzi, że Jan Paweł II „uratował duchowo wiek XXI"85. Zaś arcybiskup Wiednia, kardynał Ch. Schönborn powiedział: „To był wielki człowiek. Bardzo ludzki. Nie pouczał, nie schlebiał, mówił prosto o skomplikowanych sprawach. Potrafił dotrzeć do każdego"86. Papież został także określony jako twórca „imperium dobra i miłości bliźniego", które zostawił ludzkości. Imperium to, w przeciwieństwie do „imperium zła”, oparte jest na wartościach religijno-moralnych ${ }^{87}$. Publicysta C. Gabryś, podsumowując działalność pasterską Jana Pawła II, stwierdził, że „okazał się [on] wielkim i świętym papieżem. Był przede wszystkim żarliwym i utalentowanym duszpasterzem, który ożywił i umocnił wiarę milionów katolików na wszystkich kontynentach"88.

Innym ważnym aspektem śmierci Jana Pawła II poruszanym na łamach „Rzeczpospolitej” była atmosfera panująca w dniach żałoby w Polsce i wśród Polaków. Organizowane były Msze św., nabożeństwa, modlitwy, w których uczestniczyły rzesze wiernych, szczególnie ludzi młodych. Ten okres nazywany był "tygodniem narodowego zjednoczenia, narodowego braterstwa", duchowych rekolekcji i religijnej żarliwości. Kibice się jednali, w komercyjnych mediach dopuszczano język religijny ${ }^{89}$. Przy oka-

83 „Rz" 2005, nr 84, s. 2.

${ }^{84}$ Zob. The Weecly Standard, „Rz" 2005, nr 84, s. 2.

${ }^{85}$ A. Szostkiewicz, Ukryta sita Jana Pawta II, „Rz" 2005, nr 84, s. 9.

${ }^{86}$ Cyt. za: A. Niewiadowski, Austria czeka na zmiany, "Rz" 2005, nr 86, s. 7.

${ }^{87}$ Zob. B. Misztal, Imperium miłości, „Rz” 2005, nr 89, s. 8.

${ }^{88}$ C. Gabryś, Święty syn soboru, „Rz" 2005, nr 96, s. 17.

${ }^{89}$ Zob. P. Semka, Kościót po wielkim odejściu, "Rz" 2005, nr 85, s. 12; J. Sadecki, Wielu nawrócito się na czlowieczeństwo (rozmowa z kard. F. Macharskim), „Rz” 2005, nr 102, s. 9. 
zji spontanicznego organizowania nabożeństw próbowano niejako przeciwstawić wiernych świeckich duchowieństwu, zbytnio akcentując to, że inicjatywa niejednokrotnie wychodziła ze strony ludzi świeckich i to oni mobilizowali księży do większej aktywności duszpasterskiej $\mathrm{w}$ dniach choroby Papieża a potem $\mathrm{w}$ dniach żałoby. Stwierdzano nawet, że Kościół hierarchiczny opóźnia się ze zmianami zaproponowanymi przez Jana Pawła $\mathrm{II}^{90}$. Wiele dyskusji wywołała także inicjatywa ogłoszenia 16 października bądź 2 kwietnia Dniem Jana Pawła II, który mógłby być świętem narodowym ${ }^{91}$. W Watykanie zaś tysiące pielgrzymów odwiedzało grób Papieża-Polaka ${ }^{92}$.

\section{PUBLIKACJE W CZASIE PRZYGOTOWANIA I TRWANIA KONKLAWE ORAZ PO WYBORZE BENEDYKTA XVI}

Inną grupę publikacji stanowią artykuły łączące próbę podsumowania pontyfikatu zmarłego Papieża z określeniem zadań i oczekiwań wobec kolejnego następcy św. Piotra. W komentarzu redakcyjnym J. Moskwa napisał, że Jan Paweł II dał „katolicyzmowi bezprecedensową pozycję w świecie, a jednocześnie pozostał on mocnym "znakiem sprzeciwu” wobec prądów dominujących $\mathrm{w}$ cywilizacji współczesnej: organizacyjnie jako monarchia absolutna, ale przede wszystkim merytorycznie, broniąc tradycyjnych wartości małżeństwa i rodziny oraz świętości życia od chwili poczęcia do naturalnej śmierci" ${ }^{\prime 93}$. Od następcy oczekuje się kontynuacji, ale także pewnych innowacji. Watykaniści kreślą zróżnicowane oczekiwania wobec następcy polskiego Papieża oraz różne kandydatury ${ }^{94}$. Kiedy Papieżem zostaje kardynał J. Ratzinger, dziennikarze podkreślają jego długoletnią współpracę z Janem Pawłem II, a także podobieństwa i różnice

${ }^{90}$ Zob. E. Czaczkowska, Za mało Bożego szaleństwa (rozmowa z A. Datko), „Rz” 2005, nr 89, s. 6-7; J. Życiński, Promieniowanie duchowości, „Rz” 2005, nr 101, s. 14.

${ }^{91}$ Zob. B. Luft, Kult, pamięć $i$ naśladowanie, „Rz” 2005, nr 85, s. 2; F.G., Polacy chca święta na cześć papieża, „Rz” 2005, nr 85, s. 3.

${ }^{2}$ Zob. P. Kowalczuk, Pielgrzymi przy grobie, „Rz” 2005, nr 87, s. 7; T.T.S., Pielgrzymi odwiedzaja grób, tamże, s. 1.

${ }^{93}$ J. Moskwa, Jaki papież, jaki Kościót, „Rz” 2005, nr 90, s. 2.

${ }^{44}$ Zob. E. Czaczkowska, Ojca świętego poznamy do końca tygodnia (rozmowa z O. Petrosillo), „Rz” 2005, nr 90, s. 9; E. Czaczkowska, Zanim ujrzymy biaty dym, „Rz” 2005, nr 90, s. 8; J. Moskwa, Jakiego papieża nie chciałby Bush, "Rz" 2005, nr 90, s. 9; A. Słojewska, Opustoszałe świątynie, „Rz" 2005, nr 91, s. 6; J. Moskwa, Jakiego Kościoła życzyć nowemu papieżowi, „Rz” 2005, nr 92, s. 2. 
osobowościowe oraz inne doświadczenie życiowe, naukowe i duszpasterskie. Szeroko komentowane są pierwsze wypowiedzi Benedykta XVI oraz decyzje, z których próbuje się odczytać, w czym będzie on kontynuował dzieło swojego wielkiego poprzednika, a gdzie nastąpią zmiany ${ }^{95}$.

Dnia 13 maja podczas spotkania z duchowieństwem Rzymu w bazylice św. Jana na Lateranie Benedykt XVI ogłasza przyspieszenie procedury beatyfikacyjnej Jana Pawła II, co było spełnieniem życzenia wiernych, którzy podczas pogrzebu skandowali: "Santo subito". Jest to pierwszy przypadek tak szybkiej decyzji o wszczęciu procesu wyniesienia na ołtarze. Przy tej okazji spekulowano na temat miejsca beatyfikacji, a nawet o możliwości rychłej kanonizacji ${ }^{96} .28$ czerwca także w bazylice św. Jana na Lateranie nastąpiła uroczysta inauguracja procesu beatyfikacyjnego Jana Pawła II, któremu od tej chwili przysługuje tytuł „Sługa Boży". Zostali zaprzysiężeni członkowie Trybunału Beatyfikacyjnego, zatwierdzono tekst modlitwy o beatyfikację i po raz pierwszy ją odmówiono. Wydarzenie to spotkało się dużym zainteresowaniem mediów ${ }^{97}$. $\mathrm{W}$ dalszych miesiącach publikowano materiały związane $\mathrm{z}$ toczącym się procesem beatyfikacyjnym. Informowano o cudach dokonanych za przyczyną Jana Pawła II, o przesłuchaniach przed Trybunałem znanych osób Kościoła i polityki. Szczególną sensację wywołała wiadomość o przesłuchaniu prezydenta Polski A. Kwaśniewskiego ${ }^{98}$. Nie mniejsze zainteresowanie budziły informacje dotyczące niepublikowanych, czy też prywatnych listów i dokumentów Papieża oraz pamiątek po Nim ${ }^{99}$. Sporo uwagi wywołało opublikowanie po pięciu miesiącach od śmierci po raz pierwszy w historii Watykanu oficjalnego dokumentu, który rekonstruuje ostatnie

95 Zob. G. Górny, Na powitanie Benedykta XVI, „Rz” 2005, nr 92, s. 6; J. Moskwa, Kontynuacja i otwarcie, „Rz“ 2005, nr 93, s. 2; R. Bubnicki, Nowy papież ma w sobie coś z Jana Pawta II (rozmowa z kard. H. Gulbinowiczem), „Rz" 2005, nr 93, s. 2; P. Semka, Niemiec po Polaku, czyli cud Jana Pawta Wielkiego, „Rz” 2005, nr 93, s. 7; M. Król, Inny papież, „Rz” 2005, nr 93, s. 7; E. Czaczkowska, Koniec destrukcji wiary (rozmowa z G. Weigel), „Rz” 2005, nr 94, s. 6; J. Bartyzel, Czas zapaśników Boga, „Rz” 2005, nr 94, s. 11.

${ }^{96}$ Zob. J. Moskwa, Szybka droga do świętości, „Rz” 2005, nr 112, s. 1; E. Czaczkowska, Ku beatyfikacji w Rzymie i Krakowie (rozmowa o. S. Rytko), "Rz” 2005, nr 112, s. 2; J. Moskwa, Beatyfikacja Jana Pawła II być może w Polsce, „Rz” 2005, nr 113, s. 6.

${ }^{97}$ Zob. E. Cz., Coraz bliżej świętości, "Rz” 2005, nr 149, s. 1; J. Moskwa, Pierwszy krok do świętości, „Rz” 2005, nr 149, s. 7; E. Czaczkowska, Nowy Stuga Boży, „Rz” 2005, nr 150, s. 1; J. Moskwa, Stuga Boży Jan Pawet II, „Rz” 2005, nr 150, s. 6.

${ }^{98}$ Zob. J. Sad, Rusza przestuchania w Polsce, "Rz" 2005, nr 240, s. 5; E. Czaczkowska, J. Ordyński, Przestuchanie prezydenta, "Rz” 2005, nr 297, s. 1 i 3.

${ }^{99}$ Zob. E. Czaczkowska, Nieznany list papieża, „Rz" 2005, nr 155, s. 5. 
tygodnie życia, chorobę i śmierć Papieża. W dokumencie tym szczegółowo opisano środki lecznicze, jakim poddano Ojca Świętego, hospitalizację oraz dramatyczne wydarzenia związane $\mathrm{z}$ ostatnimi próbami przemówienia do wiernych, a także ostatnie słowa wypowiedziane po polsku: „Pozwólcie mi iść do domu Ojca"100.

Postać Jana Pawła II przywoływana jest na łamach gazety także przy okazji wydarzeń, które dotyczą jej tylko pośrednio. Do nich zaliczyć trzeba Światowe Dni Młodzieży w Kolonii, nominację nowego metropolity krakowskiego oraz sprawę ojca K. Hejmo. To Jan Paweł II był pomysłodawcą Światowych Dni Młodzieży, wyznaczył miejsce i czas spotkania młodzieży całego świata. Powszechnie oczekiwano jak Benedykt XVI w porównaniu ze swoim poprzednikiem zachowa się podczas spotkania z młodzieżą. Młodzież była przekonana, że będzie to spotkanie z dwoma papieżami: Janem Pawłem II i Benedyktem XVI ${ }^{101}$. Ważnym wydarzeniem była nominacja, przyjęcie paliusza i objęcie urzędu metropolity krakowskiego przez arcybiskupa St. Dziwisza, osobistego sekretarza Jana Pawła II ${ }^{102}$. Nadzwyczaj szeroko komentowana była także wiadomość o tym, że opiekun polskich pielgrzymów w Rzymie o. K. Hejmo - dominikanin miał być agentem tajnych służb PRL-u. W związku z tą sprawą poruszano w ogóle problem agentury w Kościele. Artykuły te miały w większości charakter demaskatorski i oskarżycielski. Świadczą o tym zarówno tytuły, jak i treść publikacji ${ }^{103}$.

100 Zob. J. Moskwa, Ostatnie stowa Jana Pawta II, „Rz” 2005, nr 219, s. 7.

101 Zob. E. Czaczkowska, Dziedzictwo Jana Pawta II, „Rz” 2005, nr 191, s. 7; tenże, Uczniowie trudnej wiary, "Rz" 2005, nr 195, s. 5.

${ }_{102}$ Zob. J. Sadecki, Z Watykanu do domu, „Rz" 2005, nr 129, s. 1; e.cz., d.z., Spetnia się wola Jana Pawta II, „Rz” 2005, nr 151, s. 1; j.sad.,e.cz., Tak chciat Jan Pawet II, „Rz” 2005, nr 200, s. 1; E. Czaczkowska, Otoczono mnie wielkg życzliwościq, „Rz” 2005, nr 200, s. 4; E. Czaczkowska, J. Sadecki, Kraków ma nowego metropolitę, "Rz” 2005, nr 201, s. 1 i 3; J. Moskwa, Brawa dla arcybiskupa Dziwisza, „Rz” 2005, nr 151, s. 7.

${ }^{103}$ Zob. J. Sadecki, Donosili na Wojtyłe, „Rz” 2005, nr 92, s. 9; A. Kaczyński, Ojciec Hejmo byt informatorem bezpieki, „Rz” 2005, nr 99, s. 1; K. Gottesman, Bolesna prawda, "Rz” 2005, nr 99, s. 2; A. Kaczyński, Donosit z Wiecznego Miasta, „Rz” 2005, nr 99, s. 5; E. Czaczkowska, Człowiek, który zdradzit papieża, "Rz" 2005, nr 99, s. 5; tenże, Kościót pozna agentów, "Rz” 2005, nr 100, s. 1; tenże, Nie będziemy udawać, że się nic nie stato (rozmowa zo.P. Kozackim), „Rz" 2005, nr 100, s. 2; E. Czaczkowska, Dominikanin zaprzecza, że donosit, „Rz” 2005, nr 100, s. 5; A. Kaczyński, Ojciec Hejmo może się odwotać (rozmowa z L. Kieresem), „Rz” 2005, nr 100, s. 5; tenże, Ojciec Hejmo przyjmowat pieniądze, „Rz" 2005, nr 101, s. 1; tenże, Co kryją akta ojca Hejmy, "Rz" 2005, nr 101, s. 3; P. Zaremba, W oczekiwaniu na odwage, "Rz” 2005, nr 102, s. 2; E. Czaczkowska, Kościót chce się oczyścić, „Rz” 2005, nr 103, s. 3; tenże, Ojciec Hejmo zawieszony, „Rz" 2005, nr 107, s. 3; tenże, Kościót zajrzy do akt, „Rz” 2005, nr 108, s. 5; e.cz., Teczki sióstr, 
Z okazji V Dnia Papieskiego, po raz pierwszy obchodzonego już bez Jana Pawła II, ukazało się na łamach gazety kilka publikacji. Informowano o różnych inicjatywach organizowanych $\mathrm{z}$ tej okazji. Była mowa o „Fundacji Dzieło Nowego Tysiąclecia” i jej stypendystach, „Instytucie Myśli Jana Pawła II”, międzynarodowej fundacji „Nie lękajcie się”, w ramach której zostanie powołane "Centrum Myśli Jana Pawła II". Wspomniano także o wystawie zdjęć papieskiego fotografa A. Mariego oraz o publikacji książki, która jest zbiorem prywatnych listów Jana Pawła II do M. Skwarnickiego. Z listów tych wyłania się osoba Papieża, która doskonale orientuje się $w$ sprawach związanych $z$ Polską, $z$ jej kultura, ze środowiskiem „Tygodnika Powszechnego"104. Nie uszły także uwagi „Rzeczpospolitej" premiery filmów o Ojcu Świętym: Karol - człowiek, który został papieżem oraz Papież Jan Pawet $I I^{105}$.

\section{ZAKOŃCZENIE}

Podsumowując pontyfikat Jana Pawła II, publicyści, naukowcy, przedstawiciele Kościoła, politycy, akcentowali różne aspekty Jego nauczania i działalności. Ks. R. Skrzypczak wskazał na rolę, jaką odegrał Papież w rozwoju personalizmu, który przeciwstawiony został zarówno indywidualizmowi, jak i kolektywizmowi. Według duszpasterza akademickiego z kościoła św. Anny, bez wizji osoby ludzkiej, jaką przedstawiał Jan Paweł II, nie byłoby ani „Solidarności”, ani młodzieży w Kolonii. Przez całą swoją działalność naukową i duszpasterską ukazywał On godność osoby ludzkiej, którą upatrywał w tym, że jest ona ,jedynym na ziemi stworzeniem, którego Bóg chciał dla niego samego" ${ }^{\prime 106}$. Jan Paweł II uznawany był także jako mistrz dialogu na płaszczyźnie religijnej, kulturowej i politycznej ${ }^{107}$.

\footnotetext{
„Rz" 2005, nr 111, s. 3; E. Czaczkowska, Nie chodzi o igrzyska, „Rz” 2005, nr 120, s. 9; A. Kaczyński, Co donosit o. Hejmo, „Rz” 2005, nr 127, s. 2; F. Gawryś, Zaginiony artykut ojca Hejmy, „Rz” 2005, nr 129, s. 3; A. Kaczyński, Oskarża i przeprasza, „Rz” 2005, nr 131, s. 4; e.cz., Glemp nie dat się zwerbować, „Rz” 2005, nr 139, s. 6.

104 Zob. E. Czaczkowska, Pierwszy raz bez Niego, "Rz” 2005, nr 242, s. 1; tenże, Jak pamiętać o papieżu, „Rz” 2005, nr 241, s. 6; M. Kuc, E. Cz., Arturo Mari dla papieża, „Rz” 2005, nr 242, s. 4; T. Wiślicki, Listy od biskupa Rzymu, „Rz” 2005, nr 242, s. 7; E. Cz., Spotkamy sie o 21.37, „Rz” 2005, nr 241, s. 6.

${ }^{105}$ Zob. B. Holender, Dużo tytutów a mało przebojów, „Rz” 2005, nr 253, s. 10; J. Bończa-Szabłowski, Świadek Boga, „Rz” 2005, nr 270, s. 17.

106 R. Skrzypczak, Personalistyczna rewolucja, „Rz” 2005, nr 205, s. 8.

107 Zob. E. Cz., Dwaj mistrzowie dialogu, „Rz” 2005, nr 218, s. 4.
} 
Po śmierci Papieża wielu komentatorów, oceniając dorobek długiego pontyfikatu Jana Pawła II, próbowało określić i ocenić sytuację Kościoła oraz wytyczyć drogi dla niego. Oczywistą jest rzeczą, że zmarły Papież wywarł wielki wpływ na kształt współczesnego Kościoła, niemniej jednak w skali globalnej Kościół jako instytucja przeżywa pewien kryzys. Wyrazem tego jest zmniejszająca się liczba praktykujących i przystępujących do sakramentów świętych, brak powołań kapłańskich. W Europie zauważa się postępującą sekularyzację społeczeństw. Istotnymi kwestiami, nad którymi Kościół będzie musiał się zastanowić, to m.in. rola kobiety we wspólnocie eklezjalnej, celibat, tzw. Kościół ludowy oraz decentralizacja władzy. W sprawach społecznych i politycznych przed Kościołem stanie zadanie podjęcia wyraźnego stanowiska wobec procesu nieograniczonej globalizacji oraz wobec nadużyć kapitalizmu ${ }^{108}$.

Publicyści piszący w „Rzeczpospolitej”, analizując nauczanie i działalność zmarłego Papieża, starali się nakreślić zadania, jakie zostawił Kościołowi i poszczególnym grupom społecznym. O. Jacek Salij podjął próbę syntezy najważniejszych dokumentów doktrynalnych Jana Pawła II. Dominikanin przywołał m.in. tak znane stwierdzenia, jak to, że „błąd komunizmu ma charakter antropologiczny”, że „ekonomia jest dla człowieka, a nie odwrotnie" czy "demokracja bez wartości łatwo przeradza się w totalitaryzm", które pokazują stosunek zmarłego Papieża do niektórych zjawisk społeczno-politycznych. Papież także zachęcał filozofów do większej ufności w zdolności ludzkiego rozumu oraz autorytatywnie stwierdził, że odrzucając Boga, neguje się najgłębsze źródło prawdziwej wielkości człowieka, ,jego transcendencję wobec świata rzeczy"109.

Jan Paweł II również dziennikarzom, których zaliczył do twórców, stawiał wysokie wymagania. M. Bajer, dziennikarka i przewodnicząca Rady Etyki Mediów, w następujący sposób ujmuje te zadania: „Skoro papież policzył dziennikarzy między artystów, czyli współuczestników dzieła stworzenia, uczepmy się tej zaszczytnej roli i próbujmy ją pełnić najlepiej. Jest to rola tłumaczy jego przesłania wszystkim pochłoniętym codziennością, utrudzonym kłopotami, niepojmującym szybko zmieniającego się świata. W hierarchii ludzi pióra tłumacze zajmują poczesne miejsce. Odpowiedzialna jest ich służba zarówno wobec autorów, jak odbiorców. Jan Paweł II

108 Zob. P. Jendroszczyk, Reform w Kościele nie da się uniknąć (rozmowa z P. Neuner), „Rz" 2005, nr 86, s. 2; A. Niewiadowski, Austria czeka na zmiany, "Rz" 2005, nr 86, s. 7; J. Moskwa, W stronę Kościoła ludowego, „Rz” 2005, nr 86, s. 7.

109 Zob. J. Salij, Wezwany do miłości, „Rz” 2005, nr 87, s. 12. 
ogromnie cenił człowieczy rozum, przy pełni serdecznej uwagi dla ludzi prostych. Był filozofem, mówił nam o największych tajemnicach Boga i człowieka. Mówił tak, że owe tajemnice nie obezwładniają, a zachęcają do cierpliwego trwania i ponawiania prób zrozumienia. Poważne media i ambitni dziennikarze powinni $\mathrm{w}$ tę stronę kierować dociekliwość i śledcze potencje - o sprawach aktualnych informując rzetelnie. I zastanawiać się, czego pragnął życzliwy Orędownik mediów"110.

Dla wszystkich katolików: duchownych i świeckich, Ojciec Święty zostawił wzór autentycznego świadka Ewangelii, który, przywracając osłabioną i zachwianą tożsamość Kościołowi, jednocześnie odważnie prowadził dialog z myślącymi odmiennie. Przekonywał $\mathrm{w}$ ten sposób, że tędy prowadzi droga Kościoła ${ }^{111}$.

Dla Kościoła w Polsce ważnym zadaniem będzie podjęcie inicjatyw w zakresie wnikliwego i głębokiego studium całej spuścizny Pierwszego Papieża-Polaka, ażeby Kościół w coraz większym stopniu był przeniknięty duchem Jego nauczania. Wśród tych inicjatyw wymienia się: powstanie Instytutu Jana Pawła II, przeprowadzenie narodowych rekolekcji na wzór wielkiej nowenny prymasa S. Wyszyńskiego, które polegałyby na corocznym (przez 9 lat) spotkaniu w miejscach, które odwiedził Papież podczas pielgrzymek do ojczyzny, ażeby tam modlić się i wspólnie medytować nad Jego nauczaniem. Inną ważną płaszczyzną działań będą dzieła miłosierdzia, np. hospicja czy rodzinne domy dziecka ${ }^{112}$.

Na łamach „Rzeczpospolitej” w 2005 roku ukazało się kilkaset słownych jednostek prasowych związanych z Janem Pawłem II, szczególne ich natężenie nastąpiło $\mathrm{w}$ okresie Jego choroby, śmierci i pogrzebu oraz bezpośrednio po tych wydarzeniach. Większość stanowiły gatunki informacyjne, tzw. newsy, mówiące o wspomnianych wydarzeniach. Ukazywały się one na pierwszych stronach gazety, w działach: „świat” i „kraj”. Były to informacje zarówno własne, jak i agencyjne. Po śmierci Papieża główny akcent został położony na gatunki opiniotwórcze, a więc artykuły, komentarze i wywiady. Dominowały one w dziale "opinie". Utworzono także na określony czas specjalny dział: „Jan Paweł II". Jak wcześniej wykazano, ukazały się także dwa numery „Rzeczpospolitej” w całości poświęcone Janowi Pawłowi II. Obok wspomnień o Janie Pawle II i podsumowań Jego

${ }^{110}$ M. Bajer, Przymierze z mediami, „Rz” 2005, nr 88, s. 13.

${ }^{111}$ Zob. C. Gawryś, Święty syn Soboru, „Rz” 2005, nr 96, s. 17.

112 Zob. E. Czaczkowska, Coś więcej niż pomniki dla papieża (rozmowa z J. Gowinem), „Rz" 2005, nr 115, s. 4. 
pontyfikatu dokonywano także prób określenia zadań, jakie stoją przed Jego następcą i Kościołem. Akcentowano zarówno sprawy, które należy kontynuować, jak i te, które wymagają zmian. Ważnym zadaniem dla mediów będzie także przybliżanie wielkiej duchowej spuścizny zakończonego pontyfikatu.

\section{DIE PRESSEMEINUNGEN ÜBER DEM PAPST JOHANNES PAUL II IN DEN SPALTEN DER „RZECZPOSPOLITA“ IM JAHRE 2005}

\section{ZUSAMMENFASSUNG}

Im Jahre 2005 erschienen, in den Spalten der „Rzeczpospolita“, ein paar Hundert verbalen Presseeinheiten, die dem Papst Johannes Paul II gewidmet wurden. Es waren sowohl die Informationsgattungen (so genannte „news"), als auch Begutachtungsmeinungen (Artikeln und Kommentare). In den ersten drei Monaten herrschten die Nachrichten über der Krankheit des Papstes, seiner Hospitalisierung, der Reaktionen der Menschen aus aller Welt auf diese Ereignisse und auch über der Lage der Kirche in dieser Zeit. Die größte Sättigung der Nachrichten verband sich aber mit dem Tod und dem Begräbnis des Papstes. Danach erschienen die Aussagen und Erinnerungen über dem verstorbenen Papst und auch die ersten Versuche, die den langen Pontifikat zusammenfassen wollten. In den Spalten dieser Zeitung gaben ihre Meinungen zu diesem Thema sowohl die Vertreter der katholischen Kirche, als auch die Politiker, Philosophen, Künstler, Wissenschaftler und Menschen, die verschiedene Weltanschauungen, politische Optionen, Religionen, und Ansichten repräsentiert haben. In diesen Aussagen wurde die Person des Papstes Johannes Paul II als eine überdurchschnittliche und charismatische Person gezeigt, die sehr bedeutende Rolle, sowohl im Leben der katholischen Kirche, die er fast 27 Jahre lang führte, als auch im Leben Polens, Europas und der Welt spielte. 
